\title{
認識に基づく地域範囲設定法と その経年的分析への応用
}

\author{
谷口 守 $^{1} \cdot$ 荒木俊輔 $^{2}$ \\ ${ }^{1}$ 正会員 工博 岡山大学講師 環境理工学部 ( \\ 2 学生会員 筑波大学大学院 環境科学研究科（干350 つくば市天王台1-1-1）
}

\begin{abstract}
高速交通網や情報基盤の整備が進んだ今日では，地域を隔てる物理的障壁の持つ意味は小さくなり，そ の境界は不明瞭になりつつある(ボーダーレス化の進展）。この結果, このような「物理的条件に基づく地 域」差よりも, 各地点がどの地域に属すると認識されているかという「認識」差の方が地域計画上重要な 意味を持つようになってきた。本研究では, このような「認識に基づく地域」を定義し, その範囲を設定 する方法を提案する．その際，指標として実際の各地点における「地名」情報を用い，地域名選択確率と いう概念を導入する。 また, 本研究で提案した地域設定法を実際に茨城県南部地方に適用し, その実用性 を検討するとともに，社会資本整備をはじめとする地域整備が地域認識に及ぼす影響について検討寸る.
\end{abstract}

Key Words : region, personal perception, borderless society, place name, infrastructure improvement

\section{1.はじめに}

東京ディズニーランドは行政区域上では千葉県浦 安市に立地しているにもかかわらず，その名称に「 東京」という地名がつけられている。 しかもそのこ とは詰りと指摘されるどころか, 一般に広く受け入 れられている.これは行政上の「東京」の範囲と， 一般に認識されている「東京」の範囲が異なること を意味し，後者の方がより広い範囲を指すことを示 唆している.

このように行政上の「東京」の範囲と認識上の「東 京」の範囲にズレが生じたのは, 積年にわたる東京 都部を中心とした都市成長, 関連する社会基盤整備, 情報発信量の拡大等がその原因として考えられる. また，こういった例は何も東京だけに限られるもの ではなく, 相対的な力関係が変化しつつあるすべて の隣接する都市や地域の間で同じ現象が観察できる. 例えば, 本研究で後ほどケーススタディとして取り 上げる茨城県「つくば」地域も，もともとは筑波山 のごく近傍を指す限定的な地名であったものが，筑 波研究学園都市の重点的な整備に伴って茨城県南部 を指す広域的な地域名称として認識されつつあると 考えられる。
本稿では研究対象としてこのような「認識に基づ く地域」に着目し, その範囲の設定法を提案すると 共に，それを経年的に適用することにより，認識レ ベルの地域範囲の変化と地域整備がそれに及ぼす影 響について考察することを目的とする．後に詳述す るが，その理由としては，近年の高速交通体系や情 報メディアの発達に伴い, 従来地域間を隔てていた 様々な障壁が取り除かれ，物理的な側面から地域の ボーダーレス化が進展していることがあげられる.

このような状況の中では主に物理的側面から規定さ れていた「行政区域」をはじめとする従来の地域よ りも, 心理的側面から規定される「認識に基づく地 域」の方が地域計画上その持つ意味の重要性を高め つつあるからに他ならない.

以下では，まず 2 。において諸研究分野における 「地域」に着目した既存の研究を概観し，ボーダー レス化社会における「認識に基づく地域」について 研究を行う意義を整理する．次に，3．ではこのよ うな「認識に基づく地域」を定義, 分析するために, 本研究では実際の地名情報や, 地域名選択確率とい う概念を新たに導入することを述へ，その考え方を まとめる．4．ではこれらの概念を用い，実際の地 域の範囲（以下，地域範囲と略）を設定する方法 
（以下，地域設定法と略）を示す．さらに，5。で は提案した地域設定法を用い, 茨城県南部地方を対 象にケーススタディを行う。特に「つくば」地域に 着目し, 社会資本整備やイベントをはじめとする地 域整備がその地域認識に及ぼした影響について検討 を行う。これらの議論をふまえ，6。では本研究で 得られた知見と課題をまとめ, さらに「認識に基づ く地域」に着目した研究の今後の発展・応用可能性 について整理する。

\section{2. 既存研究における地域概念と本研究のね らい}

\section{（1）各研究分野における既存の地域研究}

土木計画学, 地域経済学, 地理学などの各研究分 野において「地域 (region)」は研究上非常に重要な 概念である。ここでは，まず各分野において「地域」 がどのように定義されているかをみる.

はじめに, 地域経済学では『地域とは単に任意に 区分された面域 (area) ではなく, 意味の有る面域で ある.』という説明が成されている ${ }^{1)}$ 。また, 地理 学では地域経済学が述べる「意味の有る面域」の内 容として二種の類型化を行っている. 具体的には,

『地域概念には「均質空間」と「機能空間」という二つ の原理があり，このうち「均質空間」はその内部で の同一性から，「機能空間」は中心地の統合活動に 基づく結びつきから判断される.』としている ${ }^{2)}$.

一方, 土木計画学においては地域を分析単位とした 様々な研究事例は数多いが, 地域の概念や定義自体 を深く掘り下げて議論することは, 実際のところあ まり重要視されていないのが実状である。（例えば， 土木工学ハンドブックの索引項目には「地域」とい う用語すら存在しない。)

また，いずれの研究分野においても，実際の空間 を対象にした分析で用いられている「地域」は，地 理学が述べる二種の類型化のいずれかに相当してい る.すなわち，1) 地形や行政によって規定され， その内部の同一性を仮定した自治体行政域やメッシ ユを単位とし，それら相互の類似性を特定の指標に 着目し地域としてまとめた場合（均質空間）と， 2) 内部の均質性を仮定した自治体やメッシュを, 通勤者や商品のフローといった結びつき（機能空間 ）を表現するデータから通勤圈や商圈といった地域 にまとめた場合である．以上のように，これら従来 の研究では地形とか人の流れ等の物理的な観点から 一まとまりの圈域であるかどうかを判断していたこ とがわかる. 以下，本研究ではこの1)，2）のよう な地域の捉え方を「物理的条件に基づく地域」と総
称する.

これら実際の「物理的条件に基づく地域」の設定 にあたっては，具体的な統計データが具備されてい るか，もしくは調查が容易な事柄に着目した地域設 定を行わざるを得なかったといえる. また, どの研 究分野においても，地域に関わる諸理論の構筑に精 力を注いでも, それに対応するケーススタディでは 地域設定に十分注意が払われていないことも多かっ た.

一方，人間の認識という観点から地域を捉えよう とした研究は，1940 年代から地理学の分野で議論 が見られるようになり,1961 年の Lowenthal の研究 ${ }^{3)}$ 以来, 数多くの論文が発表されている $\left.{ }^{4)}, 5\right)$. その 興味の中心は，実際の測量などから作られる地図と， 我々一人一人が認識している意識上での空間認識地 図（メンタルマップ）がどのようにくい違った状況 にあるか，また，そのような空間認識というものが 個人の行動にどのような影響を与えているか検討す ることにあった。このような研究の流れは 1970 年 代半ばに行動地理学として体系化されるに至ってい る. その中には特定のサンプル調査を通じて, 広域 的な地域類型に関する認識を分析した研究 ${ }^{6)}$ も見ら れる。しかし，地域の広がりというもの自体を，そ の地域に関連する者全体の認識を追跡することによ って検討しようとした研究はない。

\section{（2）ボーダレス化社会における「認識に基づく地域」 概念の重要性}

「認識に基づく地域」を議論することの今日的な 意義はどこにあるのだろうか. 本研究ではその重要 性を以下の 3 点に整理した。

a)まず，現在の地域問題を考えるにおいて，この「 認識に基づく地域」の持つ重要性が「物理的条件に 基づく地域」に比較して相対的に高まってきたこと にある．各地域間を結ぶ交通機関が不便であったり， 情報伝達手段が十分でなかった時代において，人と 情報の流れの上から各地域は明らかに物理的に分断 されていたといえる。しかし，現在では交通機関の 発達で一日交流可能圈が拡大したり, 情報メディア の発達でどこの都市で得られる情報も大きな差が無 くなってきた。すなわち，人と情報の移動を制約す る様々な制約がとり払われ，物理的な地域の境界自 体がはっきりしなくなってきた（ボーダーレス化の 進展）といえる。ここで，ボーダーレス化とは，社 会，経済等の様々な領域で地形的，制度的，歴史的 に形成された境界が実効的な意味を失い，新しい秩 序へと転換していく過程を指す ${ }^{7)}$. ボーダーレス化 が進展すると，地域間の物理的な分断にその主たる 
根拠を求める「物理的条件に基づく地域」の持つ意 義が相対的に弱まり，かわって「認識に基づく地域」 の持つ意義が相対的に高まるのは当然の帰結である. b) また，交通条件等の物理的な条件差の重要性が小 さくなることが一因となり, 個人の行動空間は重複 した相互依存的なものになることが指摘 ${ }^{8)}$ されてお り，特に大都市の郊外部などでは通勤圈や商圈とい った地域概念を一意的に表現することは困難になり つつある。これを個人や企業といった空間における 行動主体の側から見ると，そこを「よく知っている 」とか「知っていない」といった各地域に対する認 識レベルの差がその行動に大きな影響をおよぼすこ とになる。

c)一方，これを地域の側から見ると，その地域が広 く一般に認識されているかどうかが，今日ではその 地域の死活問題につながる可能性がある。例えば, 同じ地域活性化プロジェクトを実施しても，その地 域がよく認識された地域であるかどうかでその成否 は大きく異なる。

\section{（3）必要検討事項と本研究のねらい}

このように「認識に基づく地域」の概念は，今日 の地域計画を考えるうえで非常に重要な視点となり つつある. 特に, 現在までに十分な研究が行われて いない状況のもとでは, 以下のような事柄が検討項 目として重要であろう.

a）「認識に基づく地域」を概念として説明できても， それをどのように具体的かつ理論的に定義すればよ いか.

b) また，定義を机上の空論に終わらせるのではなく， それを実空間上で検討できるようにするためには, 定義に対応するよ゙のような地域設定法とデータを用 いればよいのか。.さらにその際，認識というあいま いな現象を正確に扱い，しかも広域的な検討を可能 にするにはよ゙うすればよいのか.

c) 明確な地域設定法が定められた場合，それを現実 の空間に適用して得られる地域とは実際にはどのよ うなものなのか。 また，従来の「物理的制約に基づ く地域」では，時間的な推移に対して地域は比較的 固定的に捉えられている場合が多い。しかし，「認 識に基づく地域」では，ある地域が消失したり急拡 大するといったよりドラスティックな変化が存在す るのではないか.

d) 地域の認識に社会資本整備をはじめとする地域整 備が影響を与えているのではないか.ちょうどそれ は「物理的制約に基づく地域」間を隔てていた様々 な物理的障壁を軽減したように，「認識に基づく地 域」間を隔てる心理的障壁をも軽減するのではない
か. また，その整備に特に関連する地域の認識を高 める効果が有るのではないか.

本研究では上記したa)～d）の基礎的な疑問すべて にこたえることを目標とする.

\section{（4）本研究の特徵}

(3) で述べたa) d) の事項を検討するため, 本研 究ではそれぞれ次に対応する特徵を有する分析を行 う.

a）「認識による地域」を定義するためには，認識行 為を表現する適切な指標が必要である。本研究では それを「地名（地域名）」そのものに求める. 個人 がある地点に対して想起する数多くの地域名の中か ら, 合理的な判断を通じて最も適切な地域名を選択 (認識) すると考える. その際, ある地域名を選ぶ 可能性を「地域名選択確率」として定量化し, その 指標を用いることで「認識による地域」の定義を行 う.

b) 各地点における「地域名選択確率」を求めるため に, その名称に何らかの地域名を採用している事業 所すべてを対象とする．実際のデータ収集は事業所 の捕捉率が高く, かつ地域的・時点的に拡張性の高 い50 音別電話帳の記載データを用いる.

c) ケーススタディは茨城県南部地域全体を対象とし, 「認識による地域」の抽出を実際に行う。また，つ くば研究学園都市の整備が閣議了解された年である 昭和 38 年と平成 6 年の抽出結果を中心に，その変 化に関しても考察する。

d)さらに，対象地域におけるこの間の実際の地域整 備やイベント等に関する情報も収集し，これらが「 認識による各地域」の範囲の変化にどのような影響 を及ぼしたかについて検討を行う。

\section{3. 地名への着目と地域名選択確率の提案}

\section{（1）分析指標としての地名}

本研究では「認識による地域」を定義するために, その認識行為を表現する指標として, 各地点におい て個人が想起する「地名（地域名）」そのものに着 目することにした，そもそも地名とは「二人上の 人の間に共同に使用せられる符号」9)であり，それ を適切な形でデータとして得ることさえできれば， 認識結果を知るための最適な指標になると考えられ る.ここでは，まず地名を地域定義のための指標と して用いるにあたり，地名を対象とした既存研究を 概観し，それらの知見と課題を整理する.

土木や都市計画の研究分野において地名に着目し た研究はまだ非常に少なく, 自然災害と地名の関連 
に着目した研究 ${ }^{10)}$ の他に, 近年になってようやく笹 谷ら ${ }^{11)}$ による小地名の語彙に着目した研究や, 地名 呼称の分布に着目した仲間 ${ }^{12)}$ の研究が見られるよう になってきた.これに対し, 郷土史学, 民俗学や地 理学をはじめとする分野では既に数多くの地名研究 の蓄積 ${ }^{13 \sim 16)}$ が見られるが, その主たる研究目的等 の相違から, 本研究でそれらの成果を用いるには次 のような限界がある.

a) 基本的に「字」レベルの小地名が研究対象であり, より広域な地域レベルの地名が研究対象にされてい る例は少ない.

b) 地図や統計書の情報だけでは地名研究は不可能で あるため, データ収集法としては地道な現地でのヒ アリング調査に頼らざるを得ない。 このため, 同一 的な基準に基づく広範囲の調査は現実的に実施でき ない，また，そこに立地する者（内部者）と，外部 の者の間には多くの場合地名の呼称やその範囲にお いて, 不一致が生じることが指摘されており, 客観 的な分析を難しくしている.

c) 地名はその場所固有のものであるという視点が強 く, 定量的に普遍的なルールを見つけだすという観 点からの分析は十分でない. 内田 ${ }^{17)}$ のように, 地 域のひろがりを言及した例もみられるが，一般性の ある地域範囲の設定の仕方に関する議論は不足して いる.

\section{（2）合理的行動結果としての地域名選択}

これら従来の地名研究に対し, 本研究では地域名 はその地域に関わる個人が各地点ごとに, 最も合理 的に地域名選択（認識）を自由に行った結果得られ るものと考える。具体的には, 空間上のある地点 $\mathrm{x}$

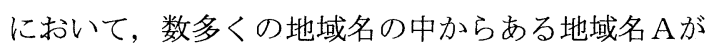
その地点の地域名として認識される可能性は, その 地点の諸条件に対応した一定の確率 $\mathrm{P}_{\mathrm{Ax}}$ （地域名選 択確率）で与えられると考える. 各地点ごとに, 地 域名として選択される可能性のある地域名の選択確 率を累積すると, 図-1に示す通りその合計值は地 点に関わらず 1.0 となる。例えば, 図-1の $\mathrm{x}$ 地点に おいて選択される可能性のある地域名が A と B 92 つであるとすれば,

$$
\mathrm{P}_{\mathrm{Ax}}+\mathrm{P}_{\mathrm{Bx}}=1.0
$$

という関係が成立する. 以下では，この地点ごとに 地域名選択確率を比較することを通じ，「認識に基 づく地域」をその範囲の広がりという観点から定義 する. すなわち, 空間上の各地点において, その地 点の名称としてそれぞれどの地域名が選ばれる可能

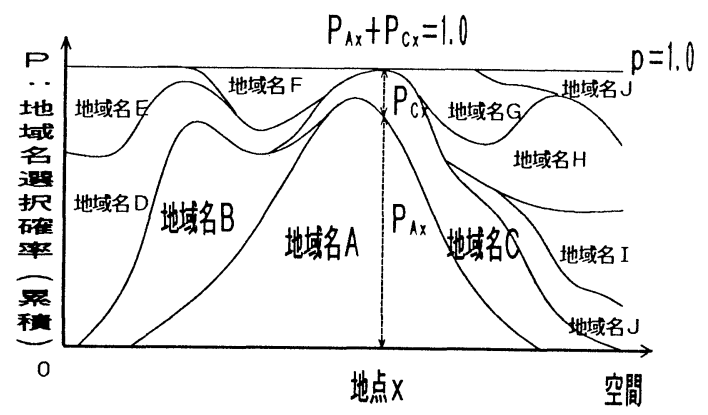

図-1 地域名選択確率の概念

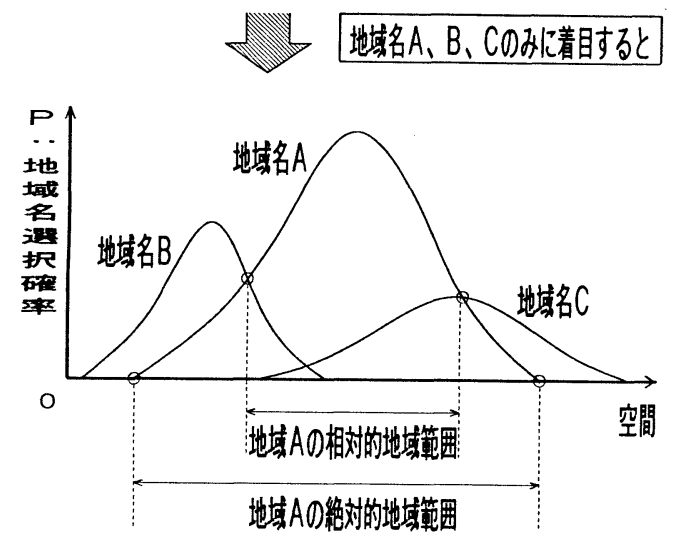

図-2 地域範囲の考え方 （図一1の地域 A, B , Cに着目して）

性が高いかということで，各地域の範囲が確定でき ると考える.

\section{4. 地域の定義と地域設定法}

\section{（1）絶対的地域範囲と相対的地域範囲の定義}

地域とは一定の空間的なひろがり（地域範囲）を 持つものであり，その範囲をどのように決めるかと いうことが，ここで考える地域の定義の中心となる． ここでは，定義を行うにあたり，図-1に含まれる 地域 $\mathrm{A}, \mathrm{B}, \mathrm{C}$ にの着目し, それらの地域名選択 確率を図-2に示した。この図から地域 $\mathrm{A}$ を例とし て考えると,「認識に基づく地域」として次の 2 通 りの考え方が提示できる.

1)他のどの地域名と比較しても，地域名 Aの選択確 率が最も高くなる空間的範囲。

2) 地域名 $\mathrm{A}$ の選択確率が 0 ではない空間的範囲. 本研究ではこの両者ともを「認識に基づく地域」を 異なる側面からあらわす定義として採用し，このう 
ち 1)を「相対的地域範囲」，2)を「絶対的地域範 囲」とそれぞれ区別して呼ぶことにする.

\section{（2）地域設定法と使用データの工夫}

以上のように「認識に基づく地域」の定義を行う ことができたが，実際の空間上でこの定義に基づく 分析を行うためには，地域名選択確率をどのような データから求めるかが重要になる. 本研究では何ら かの地域名を含む事業所名を有するすべての事業所 を対象とし, そのデータを 50 音別電話帳から収集 する方法を提案する. 具体的には, 安定した地域名 選択確率を得るのに十分な広さの地区Xを考え, 次 式で各地区における地域名選択確率を計算する.

$$
\mathrm{P}_{\mathrm{AX}}=\mathrm{N}_{\mathrm{AX}} / \mathrm{N}_{\mathrm{X}}
$$

\section{$\mathrm{P}_{\mathrm{AX}}$ ：地区Xにおける地域名 $\mathrm{A}$ の選択確率}

$\mathrm{N}_{\mathrm{AX}}$ ：地区Xにおいて事業所名に地域名 $\mathrm{A}$ を含む事 業所数

$\mathrm{N} x$ : 地区Xにおいて事業所名に何らかの地域名を含 む事業所数

この方法を採用した理由と利点は次の通りである. a) 事業所名に用いられている地域名は, その地点に おいて事業主体が最も適当之判断したものが用いら れている。しかも，その名称はその事業所の潜在的 利用者に対して提示されるものであるため, 利用者 の認識外にあり，利用者側が混乱してしまうような 地域名は事業主体にとっても採用することは難しい. つまり事業所名にどの地域名を採用するかは事業者 と利用者両方の合理的な行動（認識）に基づく結果 であるといえる。このため，このデータを用いるこ とによって, 従来の地名研究が指摘 (3.(1) c))す る内部者と外部者間の認識のずれを解消することも できる.

b) 事業所は都市活動の行われるところであれば, 普 遍的でどこにも数多く存在し，またその活動にとっ て電話は必要不可欠なため, そのほとんどは電話帳 に記載されていると考えられる。このため, 電話帳 に記載されている事業所の情報だけから十分なデー タサンプルと高い分析精度を得ることが期待できる. さらに, 電話帳には事業所の正確な名称に加え, そ の所在地も詳細に明記されており，わざわざヒアリ ング調査に出かけなくとも一度に広域のデータを得 ることができる。

c) 電話帳が整備されている年代，地域はどこでも同 じ方法で分析が可能である。このため様々な地域で 検討を行ったり，過去に遡って分析することも容易

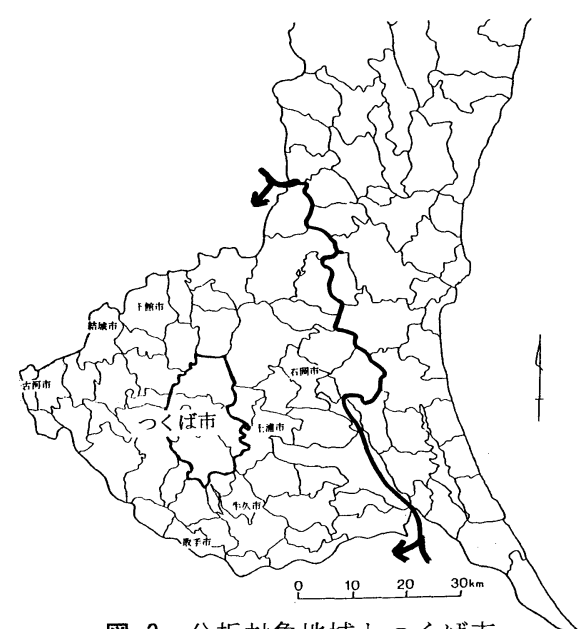

図-3 分析対象地域とつくば市

である。

また，この方法は以下のような限界を合わせ持っ ていることにも注意が必要である.

a)一口に事業所と言っても, 研究所から小売商店ま で新旧様々なものが含まれており，それぞれ対象と する市場範囲も多様である. 本論文では, 集計レベ ルの議論として, これら事業所の各属性を明示的に 扱わないが, 各事業所の地域名選択行動自体は, 各 々の事業所属性を反映しており, 必ずしも均質なも のではない.

b) 事業所は, その強弱の違いは有れ, いずれも経済 原理を前提に活動を行っているものである.このた め, その時点においてイメージの良い地域名はより 広い範囲で採用され，イメージの悪い地域名はこの 逆になると考えられる。この地域名選択行動をマー ケティング研究に対応させると，ネーミング決定に おけるプロダクトマップ上でのポジショニング戦略 に該当する行為 ${ }^{18)}$ に該当すると考えられる. しか し, 候補となる地域名が限られていること, 利用者 の認識の範囲内で選ぶ必要がること等，その制約条 件は通常のネーミング決定よりはかなり厳しいもの といえる。なお，本研究では一般利用者の認識を越 えるような地域名称を事業者は採用し得ないという 前提にたっているが，その例外となる事業所が存在 しないという保証はない.

\section{5. ケーススタディ:つくば地域における検討}

\section{(1) 分析の前提}

以下では, 本研究で提案した「認識に基づく地域」 を実際の空間上で設定するとともに, 得られた結果 をもとに, 地域整備等がその範囲に及ぼす影響につ いて検討する. ケーススタディは, 図ー 3 に示す茨 
表-1 筑波研究学園都市整備の歴史

筑波研究学園都市のあゆみ

昭和38年 (1963) 9月

昭和 42 年 (1967) 7 月

昭和45年 (1970) 5 月

昭和 47 年 (1972) 3月

昭和48年 (1973) 10月

11月

12月

昭和50年(1975) 9 月

昭和 52 年 (1977) 9 月

10月

昭和 58 年 (1983) 6 月

昭和 60 年 (1985) 1 月

3 月

3月

3月

昭和62年 (1987) 4 月

11月

昭和63年 (1988) 1 月
昭和41年(1966) 12月

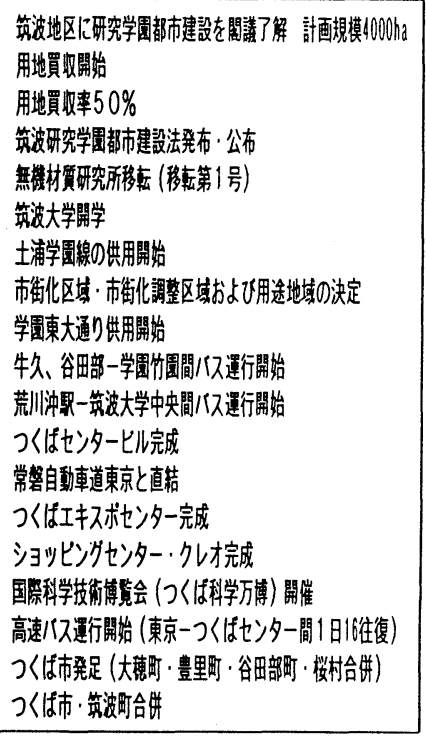

城県南部の 50 市町村を対象地域とした. 茨城県南 部には昭和 38 年 9 月にその建設について閣議了解 された筑波研究学園都市が存在し, 表- 1 に示す通 りその後 30 年間に渡って重点的な地域整備がなさ れてきた．その総資本投下量はおよそ 2 兆円にのぼ る.さらに, 近年では科学万博といった地域の知名 度を高めるイベントが行われたり, 町村合併により

「つくば市」が誕生したりしている。このケースス タディでは，このようなつくば地区への様々な整備 に伴って, 認識に基づく「つくば」の地域範囲がど のように変化したかを明らかにすることを主眼にお く. 分析対象時点は, 「つくば」整備の節目となっ た昭和 $38,48,59,61$ 年と平成 6 年の 5 時点を対象に 分析を行った. 分析結果は主に期首の昭和 38 年と 期末の平成 6 年の比較を中心に述べる.

なお，実際に地域名選択確率の検討を行ったのは， 市町村レベル以上で, 都道府県レベルよりも狭い地 域範囲を占める可能性の有る地域名を対象とした。 具体的に茨城県南部において地域名選択確率算出の 対象とした地域名は「つくば」の他に, 全市町村名, 全郡名, 常総や利根などそれ以外の名称で重要と考 えられるものあわせて全部で 86 の地名を候補とし た.また，「つくば」の呼称としてはひらかなの 「つくば」のみを対象とするのではなく，「筑波」， 「ックバ」，「筑波山」，「筑波嶺」等の地名もあ わせて抽出した。
表-2「つくば」を称する事業所数と地域名選択確率の 変化

\begin{tabular}{|c|c|c|c|c|}
\hline 地区 & $\begin{array}{l}\text { 年 次 } \\
\text { (西曆) }\end{array}$ & $\begin{array}{c}\text { 昭和38年 } \\
(1963)\end{array}$ & $\begin{array}{c}\text { 平成 } 6 \text { 年 } \\
(1994)\end{array}$ & 伸び率 \\
\hline $\begin{array}{l}\text { つくば市内 } \\
\text { 旧 } 5 \text { ヶ町村 }\end{array}$ & 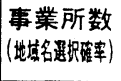 & $\begin{array}{c}34 \\
(51.515 \%)\end{array}$ & $\begin{array}{c}1348 \\
(65.724 \%)\end{array}$ & $\begin{array}{c}39.647 \\
(1.276)\end{array}$ \\
\hline 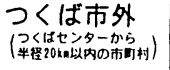 & 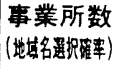 & $\left(\begin{array}{c}9 \\
(1.181 \%)\end{array}\right.$ & $\begin{array}{c}573 \\
(8.273 \%)\end{array}$ & $\begin{array}{c}63.667 \\
(7.005)\end{array}$ \\
\hline 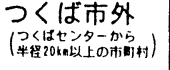 & 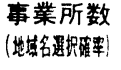 & $\begin{array}{c}3 \\
(0.454 \%)\end{array}$ & $\begin{array}{c}130 \\
(2.696 \%)\end{array}$ & $\begin{array}{c}43.333 \\
(5.938)\end{array}$ \\
\hline
\end{tabular}

次に, 実際のデータ抽出作業においては, 本研究 の目的に照らし，「ある地域名を認識し，それを事 業所の名称として用いる 1 回の行為」を 1 件として カウントした . 具体的には以下のルールに従って 50 音別電話帳からデータの抽出作業を行った.

a) 事業所（支店, 営業所も含む) の地域名は, 名 称中その地域名がどこに入っていても，その位置 に関わらずカウントする.

（例：つくば通運（株），ビジネスホテル筑波，

四井物産つくば営業所, ME C 筑波工場）

b) 地域名の選択余地のない公的施設等の地域名はカ ウントしない.

(例： $\leftarrow$ 济市役所，筑波田農協）

c) 単独事業所でないものは本社機能をもつ事業所の 地域名のみを 1 回だけカウントする.

（例：筑波ガス本社， 2 銀行筑波支店）

\section{(2) 分析の結果と考察}

対象地域において, 着目する「地域名をその名称 に有する事業所」全てを抽出したところ，昭和 38 年 においては 1,534 の, 平成 6 年においては 15,850 の 事業所が得られた。この 2 時点間において,「つく ば」を称する事業所数と「つくば」の地域名選択確 率がいかに変化したかを表-2に示す。この結果,つ つくば市内においては, 昭和 38 年から平成 6 年ま でのおよそ 30 年の間に「つくば」を称する事業所 が 1,300 件以上増加したことが明らかになった。 ま た,つくば市外においては, 半径 $20 \mathrm{~km}$ の範囲にお いて「つくば」の地域名選択率確率が 30 年前のお よそ 7 倍に， $20 \mathrm{~km}$ 以遠の範囲ではおよそ 6 倍に増 加したことが明らかとなった.

さらに, 昭和 38 年から平成 6 年までの間に,「つ くば」の絶対的地域範囲と相対的地域範囲がどのよ うに変化したかについて, 図-4〜図-7に示す。 
凡 例

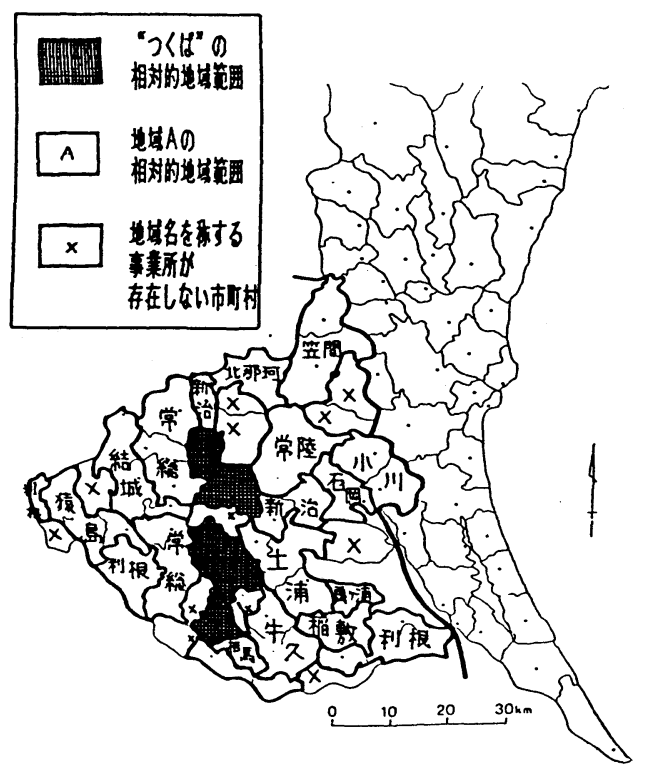

図-4 昭和38年におりる茨城県南部の相対的地域範囲

凡例

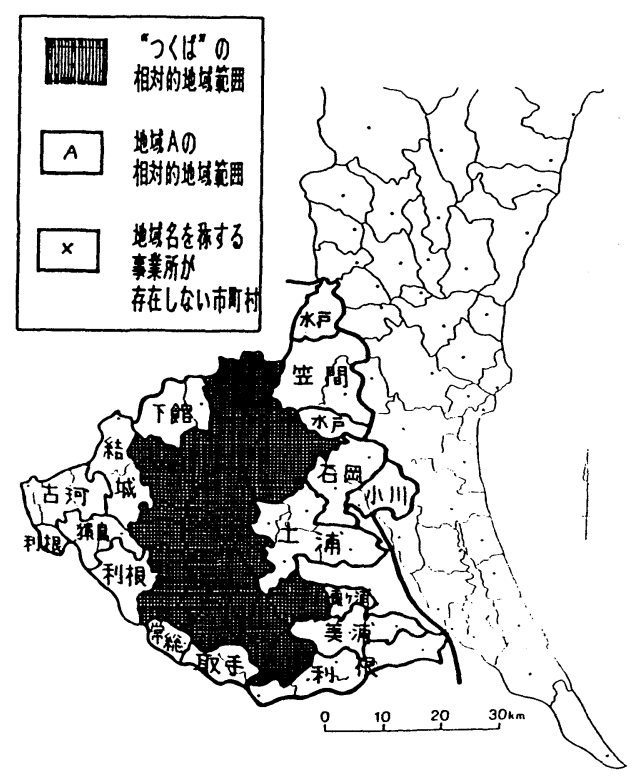

図-5 平成6年における茨城県南部の相対的地域範囲

(これらの図では見やすいように市町村レベルで結 果を示している. データの性格上, より細かい地区レ ベルを単位とした分析も可能である。）これらの結 果から, 平成 6 年にはつくばの相対的地域範囲は茨 城県南部に広く拡大していることがわかる。これを， 昭和 38 年に茨城県南部を代表するような地域名が 存在しなかった状況と対比すると, つくばへの地域

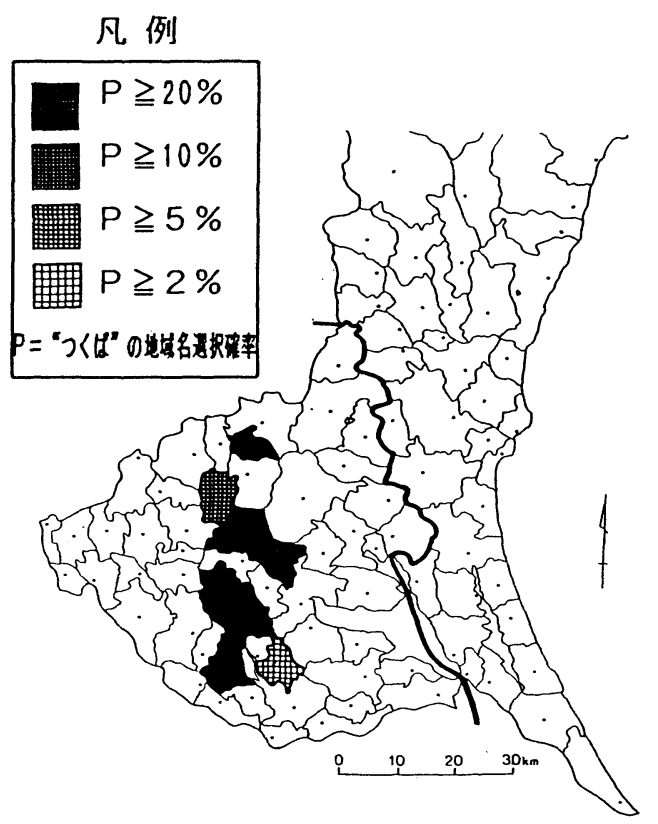

図-6 昭和38年における「つくば」の絶対的地域範囲

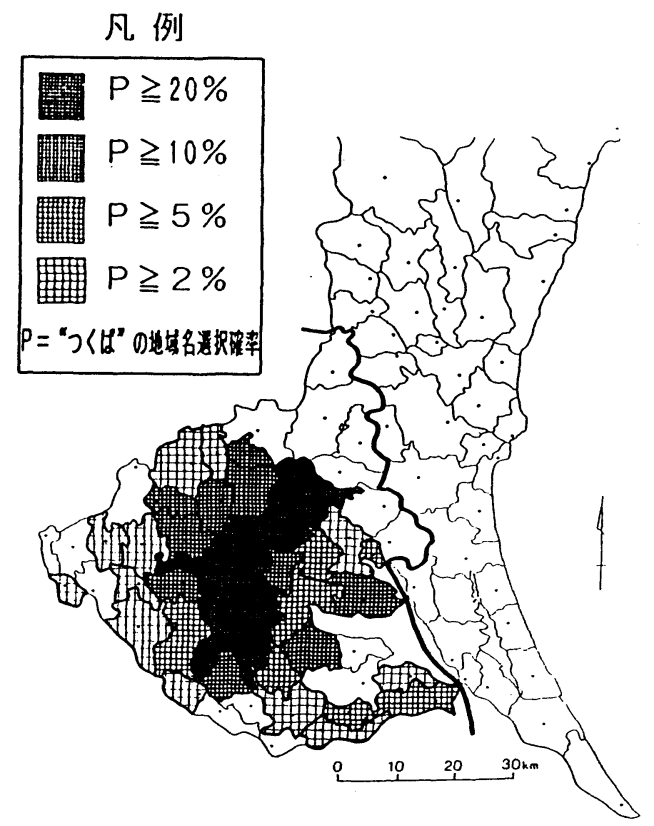

図-7 平成6年における「つくば」の絶対的地域範囲

整備が急速にその地域名選択確率を高めてきたと考 えられる。また，相対的地域範囲のみならず，絶対 的地域範囲でみても，「つくば」地域の外縁はかな り広がっており, 現在「つくば」の相対的地域範囲 に属していない市町村においても，「つくば」の地 域名選択確率は確実に上昇している。一方, 変化し た地域名称に着目すると, 常総, 新治などの古来か 
古来からの地域名称で乎ばれた地域が，近年特にそ の地域範囲を縮小していることがわかる.

時点別の分析から，「つくば」の地域名の選択確 率は経年的に増加しているが, の中でも昭和 61 年 以降の最近の伸びが相対的に大きいことが明らかに なった.この要因として考えられるのは昭和 63 年 におけるつくば市の誕生である。このことは，認識 による地域の拡大が，つくば市という新たな行政上 の地域を生み，それがまた認識による地域の拡大に つながっていった循環的構造を読みとることができ る.

一方，図ー7から地域名「つくば」の選択確率が, つくば市からの距離に必ずしも比例していないこと が読みとれる。このほとんどは，茨城県南地域にお ける旧来の中心地（例えば土浦市等）の影響による ものであり，そのようなところでの「つくば」の選 択確率はその周辺市町村と比較して, 相対的に低く なることによるものである.

以上の結果から, 茨城県南部地方では「つくば」 を中心に「認識に基づく地域」が 30 年ほどの間に, 地域整備等の影響を受けて急激に変化していること が明らかとなった。

\section{6.おわりに}

\section{（1）本研究のまとめと課題}

本研究では, 物理的な諸条件が明確に地域を隔て ることが少なくなった現代のボーダーレス化社会に おいて，「認識」が規定する新たな地域概念の重要 性を指摘した。 また，各事業所活動の地域名選択が 個々の合理的な判断によってなされていることに着 目し，地域名選択確率という概念を導入して「認識 に基づく地域」を定義すると共に，簡便で適用性の 高い地域設定法を考案した。ささに，実際に茨城県 南部を対象に「認識に基づく地域」を設定し，その 経年的変化と地域整備が及ぼす影響について検討を 加えた.

以上, 本研究では「認識に基づく地域」分析のた めの, 一つの基礎的な枠組みを提示した. この方法 を用いることによって, 特定地域の認識上の盛衰を 追跡することが可能である.また，本論文で提案し た方法を，地域認識を高める政策の実施効果把握の ために応用することも考えられる。しかし，地域が 認識されるということの本質的な意義と, その計画 論的な評価については更なる議論が必要である.

また, 分析上の課題としては, 各事業所の属性の 違いまで考慮したうえで, 従来から規定されてきた 商圈等の様々な圈域と認識による地域の対応関係を
明らかにする必要がある．また，最初は多少不自然 でも，特定の事業所に採用された地域名が，時間の 経過とともに社会的に認知され，一般化していく場 合のプロセスを具体的に明らかにすることも重要で あろう。

\section{（2）研究の発展可能性}

最後に, 本研究で得られた知見を参考に, 今後「 認識に基づく地域」に着目した研究の発展可能性に ついていくつかの方向性を述べる.

\section{a) 地域名選択確率から地域知名度の分析へ}

本研究で提案した地域名選択確率は, 各地点にお ける各地域の認識度の高さを表現するものである. このため, 地域名選択確率曲線を, 各地点における 人口等でウェイト付けしながら全空間に渡って積分 すれば，その地域の被認識度（すなわち知名度）の 高さを表現する指標を提案することができる.

\section{b) 認識に影響を及ぼす要因のモデル分析}

認識に基づく「つくば」地域の拡大には，社会資 本整備とつくば万博による情報発信量の拡大，「つ くば」市としての町村合併等様々な要因が重複した 結果であることが考察できた.これを地域側の視点 に立って考えると，どのような方策が地域名選択確 率曲線を上昇させるのに有効であったか, 様々な要 因に基づく効果を分離して知ることができれば有益 であろう．説明変数を特定し，対応するデータを収 集することは容易ではないと思われるが，非集計行 動モデルを用いた地域名選択行動のモデル分析や， 数量化 II類, 判別分析モデルによる地域名選択に影 響を及ぼす諸要因の定量的検討が考えられる.

\section{c) 都市機能ごとの地域認識について}

同じ一つの地域でも，想定する都市機能が異なる と，対応する「認識に基づく地域」の範囲が異なる 可能性がある．例えばつくばの例だと「商業機能」 に着目した場合に認識される範囲よりも，「研究開 発機能」に着目した場合に認識される範囲の方が広 域である可能性が高い。このような「認識」の中身 について，より詳細な検討が必要となろう.

\section{d) 非連続空間への応用}

地域認識の波及は，何も空間的に連続した範囲の みで生起する事象であるとは限らない，例えば，地 方都市 $\mathrm{A} に お け る \mathrm{~N}$ 商店街が「A 銀座」と乎ばれた り，地方 Bにおけるこぎれいな都市 $\mathrm{M}$ が「Bの小京 都」と呼ばれたりすることがある.これは，同じ商 店名でも「N」より「銀座」という名称の方が，ま た同じ都市名でも「M」より「京都」という名称の 方が認識という点ではより上位にあることによる. このような非連続空間上における地域認識も興味深 
い研究テーマとなろう.

謝辞 : 本研究の実施にあたっては，筑波大学黒川洸 教授, 石田東生助教授, 大野栄治講師から有益なコ メントをいただいた。また，日本地名研究所事務局 長の金子欣三氏には地名研究に関する適切な御助言 をいただいた。 さらにデータ収集においては, 违信 総合博物館中野美智子氏のご協力を得た。ここに記 して謝意を表する.

\section{参考文献}

1) Walter Isard : Introduction to Regional Science, Prentice-Hall Inc., 1975.（青木・西岡訳：「地域科 学入門 (I)」, 大明堂, pp.1-3, 1980.)

2) 青木伸好：地域の概念, 大明堂, pp.6-13， 1985.

3) Lowenthal, D. : "Geography, experience, and imagination: towards a geographical epistemology," Annals of the Association of American Geographers, Vol.51, pp.241-260

4) Cox K. \& R. Golledge : Behavioral Problems in Geography Revisited, Methuen，1981.（寺阪昭信 監訳：「空間と行動論」, 地人書房, 1986. )

5) 中村豊, 岡本耕平：「メンタルマップ入門」, 古今 書院, 地理学選書, 1993.

6) Cox, K. \& G. Zannaras : "Designative perceptions of macro-space", Downs, R.M.\& D. Stea (eds.), Image and Environment, Aldine Publishing Co., 1973. (吉武泰 水監訳：「環境の空間的イメージ」，第 10 章，鹿 島出版会, 1976.)

7）小森星児：「地域開発と国土計画」，人文地理，第 3 章, p.27, 大明堂, 1994.

8）藤井正 : 大都市圈における地域構造研究の展望, 人 文地理, Vol.42, No.6, pp.40-62, 1990

9) 柳田國男: 地名の研究, 柳田國男全集, No.20, p.16，ちくま文庫， 1990 .

10) 小川豊 : 危険地帯がわかる地名, 山海堂, 1983.
11) 笹谷康之, 中岡浩, 小柳武和, 山形耕一：小地名を 用いた環境情報の研究, 都市計画論文集, No.24, pp.607-612，1994.

12）仲間浩一：地名呼称の分布に見る地区イメージの 伝搬に関する研究, 都市計画論文集, No.29, pp.607-612， 1994.

13）例えば，谷川健一：現代「地名」考，日本放送出版協 会, 1979 .

14）大石湛山：地名改変の歴史／古代から近世まで, 地 名と風土（谷川健一編）, 第 1 号, pp.54-63, 三 省堂, 1984 .

15) 千葉徳爾 : 新·地名の研究, 古今書院, 1994.

16）一志茂樹：地名調查について，地名と風土（谷川 健一編），第 3 号，pp.7-16，三省堂， 1985.

17) 内田順文：軽井沢における「高級避暑地・別荘地」 のイメージの定着について, 地理学評論, 62A-7, pp.495-512, 1989.

18) 片平秀貴 : マーケティング・サイエンス, 東京大学 出版会, pp.123-146, 1987.

19）木内信蔵：地域概論，東京大学出版会， p. 97 , 1968.

20) 久保田治夫：筑波研究学園都市，筑波書林，1981.

21） NTT, 電報電話局 : 50 音別電話帳, 茨城県南部地 方関連版，1963.1973. 1984. 1986. 1994.

22）朝野洋一, 寺阪昭信, 北村嘉行: 地域の概念と地域 構造, 大明堂, 1988.

23) 長谷川典夫他：現代都市の空間システム, 大明堂, pp.143-175， 1992.

24) 西村睦男 : 中心地と勢力圈, 大明堂,pp.51-81,1977.

25) 土木学会編 : 土木工学ハンドブック, 第 4 版, 1989.

26）石見利勝, 田中美子：地域イメージとまちづくり， 技報堂出版，1992.

\section{THE DESIGNATION METHODOLOGY OF REGIONS BY PERSONAL PERSEPTION AND IT'S APPLICATION FOR TIME SERIES ANALYSIS}

\section{Mamoru TANIGUCHI and Shunsuke ARAKI}

High-speed transport systems and communication technologies have gradually destroyed physical obstacles among regions. Under such a kind of borderless society, the concept of "regions based on personal perception" becomes more important for regional planning, than the concept of "regions based on physical conditions". This study provides the definition and the designation method for "regions based on personal perception". In the method, the idea of "Probability of place name choice" is adopted. Case study on southern part of Ibaragi prefecture shows the usefulness of the method. The effects on personal perception by infrstructure improvement are also evaluated 